\title{
The archbishop's dinner? Late medieval fish from Esztergom-Várhegy-Kőbánya, Hungary
}

\author{
László Bartosiewicz ${ }^{1}$ (D) $\cdot$ Erika Gál $^{2}$ (D) \\ Received: 14 December 2020 / Accepted: 13 May 2021 / Published online: 10 July 2021 \\ (C) The Author(s) 2021
}

\begin{abstract}
Fourteenth-fifteenth century food refuse from the kitchen of the Esztergom archbishopric shows a significant diachronic increase in cyprinid bones, in particular those of carp. Meanwhile, contributions by large acipenserids and carnivorous species (catfish/ wels, pike, percids) declined. Contemporaneous account books indirectly suggest that the archbishop's kitchen must have increasingly relied on farmed carp fish. Sturgeons were a commodity sold by the archbishopric but rarely consumed. Expensive pikes were bought at low prices for the archbishop, possibly related to the small size of individuals found in the deposits. The poor representation of high-status fish is consonant with the scarcity of bones from large game in an assemblage dominated by domesticates. Wild game is represented by brown hare, partridge, and a variety of thrushes. These finds confirm that the foodways in the archbishop's palace were more modest than expected on the basis of its social status. Increasing contributions by cyprinids and sterlet to the assemblage also coincide with the high relative frequency of their recipes in a sixteenth century cookbook.
\end{abstract}

Keywords High-status diet $\cdot$ Carp fish $\cdot$ Pike $\cdot$ Sturgeon $\cdot$ Fowling $\cdot$ Fish ponds $\cdot$ Account books

"Then game and fish and ev'ry dish / That lures the taste and sight / A hundred hurrying servants bear / To please the appetite."

(János Arany: The Bards of Wales, 1857. Translated by Watson Kirkconnell)

\section{Introduction}

During the High Middle Ages, a relatively homogeneous courtly culture emerged across Europe. Consuming a variety

This article is part of the Topical Collection on Fishing Over the Millennia

László Bartosiewicz

laszlo.bartosiewicz@ofl.su.se

1 Osteoarchaeological Research Laboratory, Stockholm University, Stockholm, Sweden

2 Institute of Archaeology, Research Centre for the Humanities, Budapest, Hungary of fish, hunted game, and wild birds played key roles in asserting social status. Among high clergy, religious dietary restrictions stimulated the consumption of high-quality fish. Meat provisioning for common people in medieval Hungary was based on livestock. Fishing and hunting were closely regulated. Written sources reveal the economic significance of fish exploitation across Central Europe (Hoffmann 1997), while hunting was a luxury of the elites.

The Esztergom archbishopric was established in AD 1001, the archbishop being the highest-ranking representative of the Catholic Church in Hungary. Fourteenth-fifteenth century food refuse from the archbishop's palace excavated at Esztergom-Várhegy-Köbánya offered an opportunity to test the hypothesis that inhabitants and guests of this venue indulged in the bounty offered by the nearby Danube River and neighbouring forests.

A preliminary study, however, revealed the dominance of ordinary livestock in the diet (Gál 2021). Among mammals, cattle (Bos taurus) made up 39.7\% of 3071 identifiable bones (number of identifiable specimens, NISP henceforth), while pig (Sus sp.) and sheep (Ovis aries) contributed $29.1 \%$ and $31.2 \%$, respectively. Although no goat (Capra hircus) bones were found, only 58 of the 959 caprine remains could be identified as those of sheep. None of the likely domestic pig 
remains stood out by size as evidence of boar hunting. These percentages were nearly identical in the fourteenth and fifteenth century deposits $\left(\chi^{2}=5.396, \mathrm{df}=2, \mathrm{P}=0.067\right)$. Beef provided the bulk of the meat; the proportion between mutton and pork was balanced. No horse (Equus caballus) bone was found, while sporadic remains of dogs (Canis familiaris) and cats (Felis catus) were mixed with the food refuse. The 84 bones of mice (Mus sp.) and rats (Rattus sp.) were a natural addition to this deposit. Large game was poorly represented. Only two bones of red deer (Cervus elaphus) and roe deer (Capreolus capreolus) each were found although 102 red deer and two roe deer antler fragments were also recovered. The proximal phalanx of a brown bear (Ursus arctos) in the fifteenth century deposits may be indicative of bear paw, a known delicacy, but may also originate from the animal's skin. This analysis is focused on the fish consumed at the archbishop's court. Birds and hare (Lepus europaeus) have also been considered qualitative indicators of the diet.

\section{Materials and methods}

Esztergom Castle occupies an elevation $>50 \mathrm{~m}$ above the floodplain (Fig. 1) on the right bank of the Danube, where the river leaves the Small Hungarian Plain and enters the Danube Bend gorge. Food refuse from the archbishop's kitchen accumulated on the hillside in an abandoned quarry below the castle. Animal remains were protected in the thick deposit, no weathering was observed. They were recovered by dry screening using 2 and $5 \mathrm{~mm}$ mesh sizes. The stratigraphy of the deposit was divided into five major sets of layers, of which sets II and III were undisturbed. Set II contained approximately one-third of the material, radiocarbon dated to the fifteenth century (AMS radiocarbon dating). Set III, radiocarbon dated to the fourteenth century, included almost two-thirds of the animal remains. A small number of bones recovered from set IV at the bottom of the deposit were used to complement information from sets II and III.

Fish bones were measured following Morales and Rosenlund (1979). Acipenserid measurements were compared to the great sturgeon (Huso huso) in Hungary (Bartosiewicz and Takács 1997). Total lengths (TL) of pike (Esox lucius) and catfish (Silurus glanis) were estimated using present-day reference data from Sweden (Bartosiewicz 1990) and Hungary (Takács 1987). Cyprinid measurements were analysed after Libois and Hallet-Libois (1988). Total length estimates were compared to those in the literature (Bielichová et al. 2019; Piličiauskienè and Blaževičius 2019), and
Fig. 1 The landscape around Esztergom seen from west by Joris Hoefnagel, AD 1595 (top) and the location of Esztergom (1) in present-day Hungary (bottom). Sites mentioned in the text: (2) Visegrád and (3) Buda. Images in the public domain

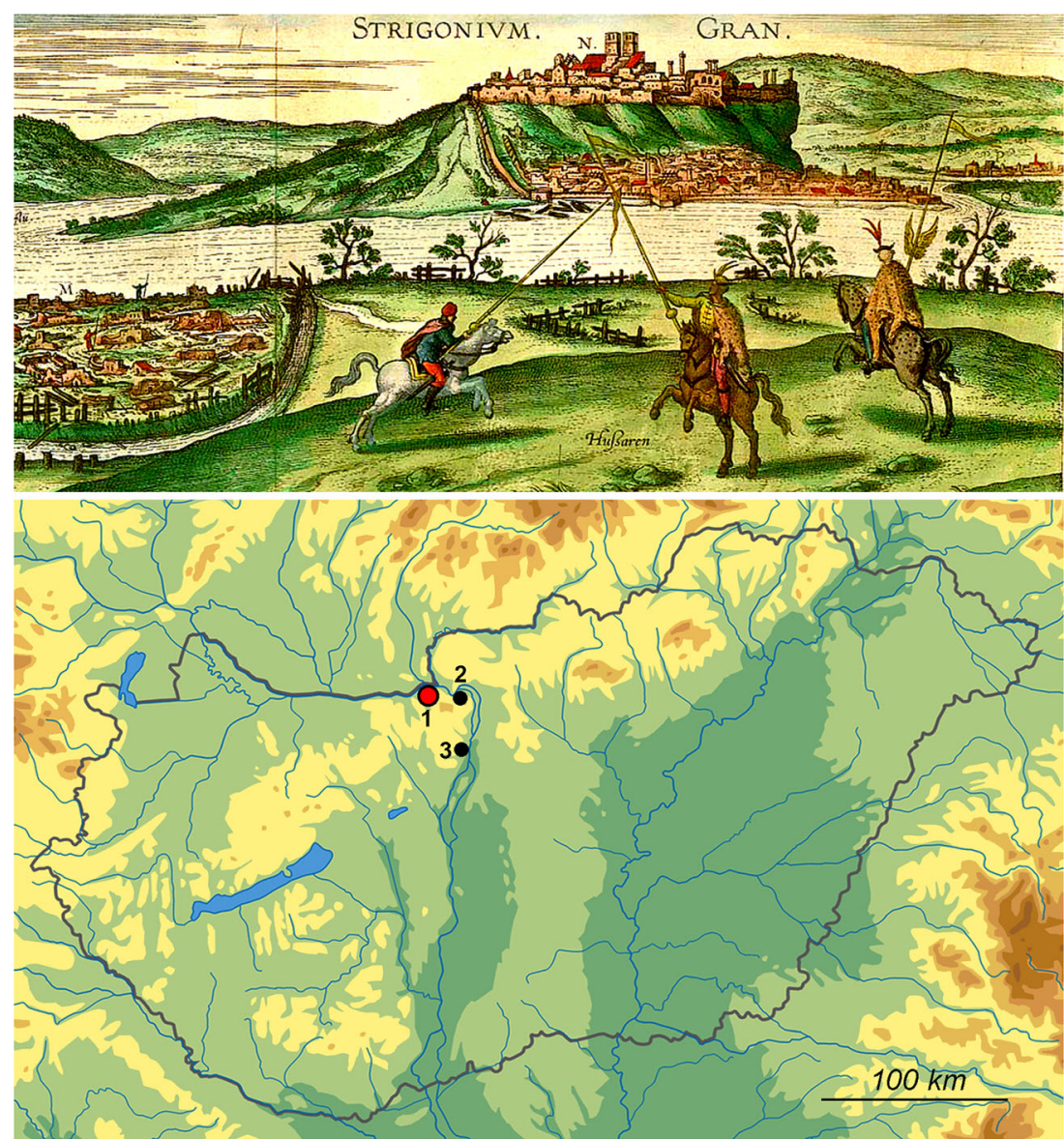


references to fish sizes in the kitchen account books of Ippolito d'Este (Pro Coquina castri, 1489), a cardinal from Ferrara, who first served as Archbishop of Esztergom (AD 1486-1497) and then in Eger (AD 1497-1520).

As the archaeological remains dated from the fourteenth century, it is unfortunate that no documentary sources of comparable quality and detail are available prior to the arrival of Ippolito d'Este and his court from Renaissance Italy. Twentyeight of the account books of his kitchen from Esztergom and eight from Eger have been inventoried and analysed (Nyáry 1867). They contain daily lists of items purchased and sometimes sold, along with relevant prices. They may thus be regarded as a relatively objective source, containing both quantitative and seasonal information. The only source of bias may be that pedantic Italian account officers such as Piero Pincharo may have encountered difficulties translating and recording Hungarian names and titles, as well as units and varieties of income. Although expenses recorded in these accounts far outweigh documented income, it has been debated whether these accounts already represent an early form of double entry bookkeeping, invented in Venice at around this time (Kuffart 2018).

There were twice as many fish bones in the fourteenth century sub-assemblage (total NISP $=4380$ ) as in the fifteenth century set (total NISP $=2180$ ). Within these, the numbers of all fish remains are summarized in Table 1. Due to the difference in assemblage sizes, species representation needs to be interpreted cautiously: taxonomic diversity as a function of assemblage size varies between vertebrate classes (Bartosiewicz and Gál 2007). The diachronic homogeneity of taxonomic composition was tested using chi-square $\left(\chi^{2}\right)$ tests. The significance of results was considered at the conventional $\mathrm{P} \leq 5 \%$ level of probability.

\section{Results}

The composition of all 6560 identifiable animal remains in the studied stratigraphic sets is shown by animal classes in Fig. 2a. The representation of domesticates did not change between the fourteenth and fifteenth centuries: the source of significant difference is the increasing relative contribution of fish from 17.6 to $18.4 \%$ in the smaller, fifteenth century subset (Fig. 2a). Moreover, the taxonomic composition also differs significantly between the two fish assemblages due to a diachronic increase in carp (43 to $47 \%$ ) and small cyprinids (19 to $28 \%$ ) at the expense of other species (Fig. 2b). By the fifteenth century, the relative contributions of acipenserids and pike to NISP shrunk by about a third; the percentage of catfish also declined.

Aside from acipenserids, most of the fish identified are eurytopic, tolerant of wide variations in habitat. Exceptions include percids, barbel (Barbus barbus), and vimba bream (Vimba vimba). These rheophilic species prefer rapid current: the two cyprinids have been observed in streams of the nearby Visegrád hills (Weiperth et al. 2015). Remains of freshwater
Table 1 The taxonomic composition of aquatic remains. The sums of major categories are indicated in bold print

\begin{tabular}{|c|c|c|c|c|}
\hline & Bottom & Fourteenth c. & Fifteenth c. & Total \\
\hline Great sturgeon (Huso huso L., 1758) & 1 & & 1 & 2 \\
\hline Sterlet (Acipenser ruthenus L., 1758) & 5 & 43 & 13 & 61 \\
\hline Large acipenserid (Acipenseridae) & 2 & 35 & 15 & 52 \\
\hline Pike (Esox lucius L., 1758) & 13 & 128 & 45 & 186 \\
\hline Carp (Cyprinus carpio L., 1758) & 21 & 120 & 95 & 236 \\
\hline Bream (Abramis brama L., 1758) & & 4 & 9 & 13 \\
\hline Barbel (Barbus barbus L., 1758) & & 4 & 2 & 6 \\
\hline Crucian carp (Carassius carassius L., 1758) & 1 & 6 & 1 & 8 \\
\hline Ide (Leuciscus idus L., 1758) & & 8 & 2 & 10 \\
\hline Roach (Rutilus rutilus L., 1758) & 1 & 4 & 3 & 8 \\
\hline Tench (Tinca tinca L., 1758) & & 2 & & 2 \\
\hline Vimba bream (Vimba vimba L., 1758) & & 3 & & 3 \\
\hline Small carp fish (Cyprinidae) & 35 & 246 & 144 & 425 \\
\hline Catfish (Silurus glanis L., 1758) & & 17 & 4 & 21 \\
\hline Perch (Perca fluviatilis L., 1758) & & 2 & 1 & 3 \\
\hline Pikeperch (Sander lucioperca L., 1758) & 3 & 12 & 5 & 20 \\
\hline Freshwater crayfish (Astacus sp.) & & 2 & 1 & 3 \\
\hline Total NISP & 82 & 636 & 341 & 1059 \\
\hline Non-identifiable fish (Pisces sp. indet.) & 8 & 134 & 60 & 202 \\
\hline Total & 90 & 770 & 401 & 1261 \\
\hline
\end{tabular}




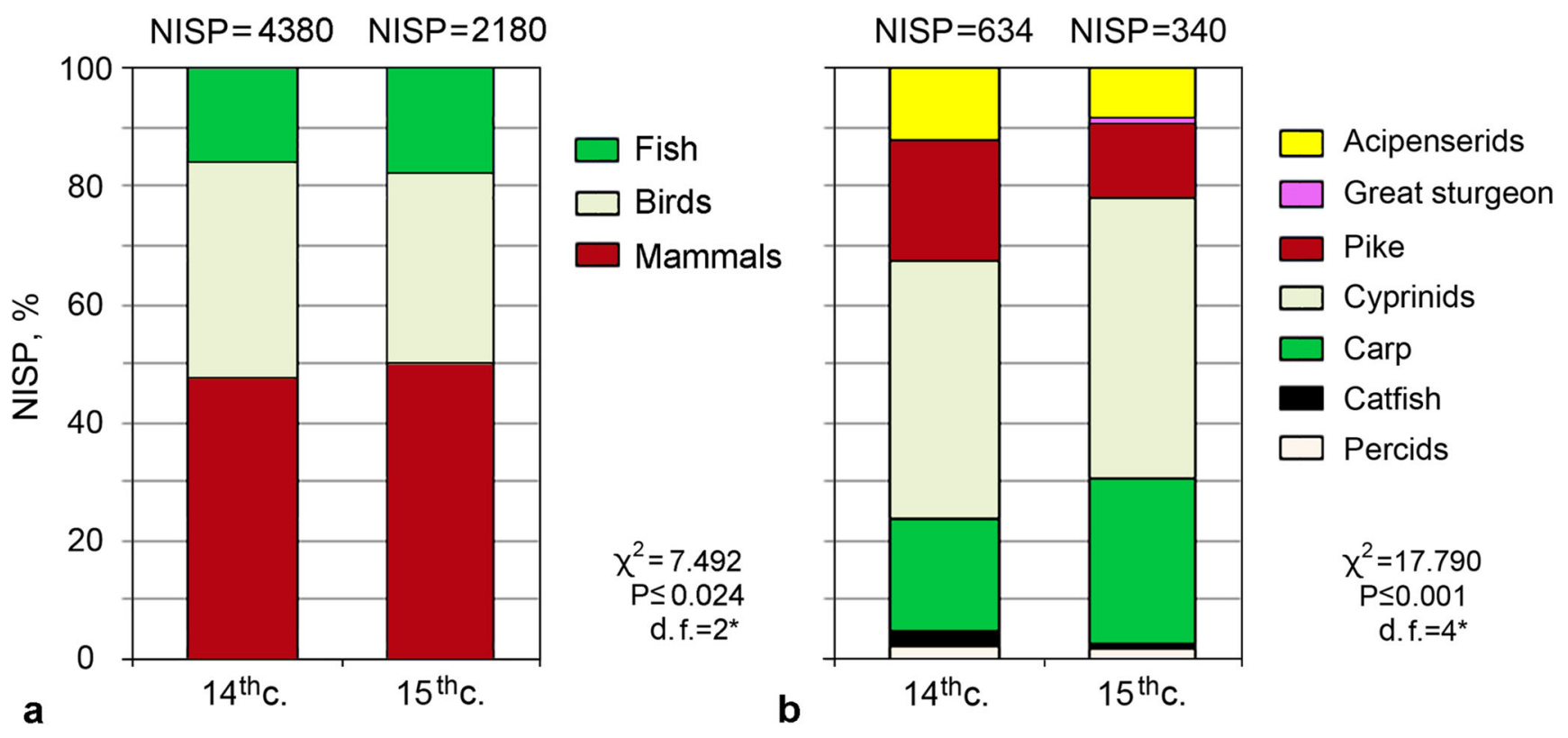

Fig. 2 The distribution of the number of identifiable specimens (NISP) by vertebrate classes (a) and among fish taxa (b) in the main chronological sets

crayfish (Astacus sp.) also indicate clear waters, rich in dissolved oxygen.

Of the species listed in the account books of Ippolito d'Este, carp, pike, barbel, crucian carp (Carassius carassius), and catfish were identified among the finds. His records also mention asp (Aspius aspius), a maximum 70- to 80-cm-long carnivorous cyprinid and burbot (Lota lota), the only freshwater gadiform. A synonym for 30 - to 60 -cm-long burbot in Hungary is "winter catfish", as it is popular in ice fishing.

\section{Acipenserids}

Two species that can be recognised by size are sterlet (Acipenser ruthenus; $\mathrm{TL}=1-1.2 \mathrm{~m}$ ) and the great sturgeon ( $\mathrm{TL}=2-3 \mathrm{~m}$ ), a difference visible in Fig. 3. However, Russian sturgeon (Acipenser gueldenstaedtii), ship sturgeon (Acipenser nudiventris), and stellate sturgeon (Acipenser stellatus) also occurred in the Danube (Bartosiewicz et al. 2008). Non-diagnostic acipenserid bones of transitional sizes form the "large acipenserid" category. Ossified dermal scutes (Fig. 3d), characteristic of some species (Brinkhuizen 1986), are among the best preserved acipenserid bones. Y-shaped pectoral fin rays can be used in estimating the total length of sturgeon (Desse-Berset 1994).

Sterlet, frequently served at the Esztergom archbishopric, can grow larger than the average carp or pike. It prefers riverine habitats with high concentrations of dissolved oxygen (3.0-3.5 mg/l; Pénzes and Tölg 1977). Measurements of 14 pectoral fin rays show that most were shorter than $1 \mathrm{~m}$ long prior to the fifteenth century (Fig. 4a). Ten pectoral fin rays yielded a mean length of $58.7 \mathrm{~mm}$ (standard deviation $=8.5$ $\mathrm{mm}$, range $=48.3-74.5 \mathrm{~mm}$ ). There are no methods to convert the lengths of fragile fin rays to total body length in acipenserids. The parameters of pectoral fin ray length, however, are consonant with the distribution of estimates based on the greatest width of its articular end as shown in Fig. 4a.

Unlike freshwater sterlet, other acipenserids were migrating upstream from the Black Sea for spawning prior to the construction of the Iron Gates dams across the Danube in AD 1971 and 1984 (Bartosiewicz et al. 2008). The run fell between January and June and they returned to the sea between October and December (Bél 1764). Masses were caught in weirs built at elevations of riverbeds or in shallows. A measurable great sturgeon fin ray came from an almost 3.5m-long fifteenth century specimen. A non-measurable but even larger proximal fin ray fragment was found at the bottom of the deposit (Fig. 3c). These bones illustrate the rare consumption of this valuable fish. In an AD 1329 account book from Zsolca near the Sajó river in eastern Hungary, the tax for great sturgeon was two denarii, while for other sturgeon species it was only one denarius. Even this smaller sum would have been equal to the tax on a horse, ox, or cow (Tóth and Kubinyi 1996).

\section{Pike}

Pike, highly appreciated for its dry meat, is an aggressive carnivorous fish, popular in heraldic art. It is active yearround and can be caught during the winter. Robust pike bones are common in hand-collected assemblages. By the first summer, young pikes reach a total length of $0.2 \mathrm{~m}$ and prey upon anything smaller than themselves. Fully grown males reach 1 $\mathrm{m}$ and females grow to about $1.5 \mathrm{~m}$ by the age of between 8 and 9 years (Berinkey 1966). Archaeological assemblages 


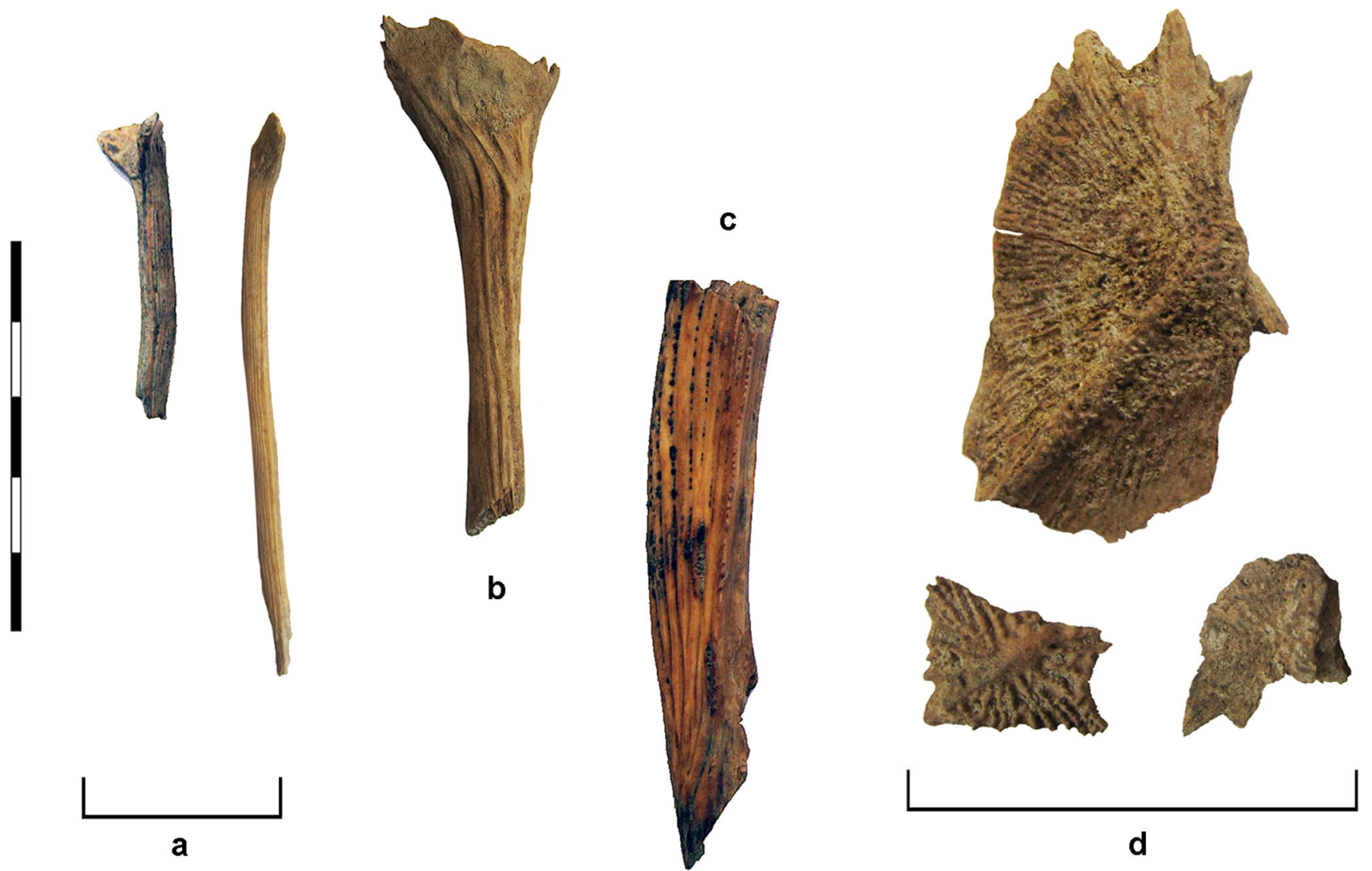

Fig. 3 Pectoral fin rays of sterlet (a) and sturgeon (b fourteenth century; $\mathbf{c}$ bottom layer); and dermal scutes from large acipenserids (d). Scale $5 \mathrm{~cm}$

often contain pike bones of various sizes along with small cyprinid remains, especially close to eutrophic rivers with rich vegetation (Heinrich 2012/13).

Young pikes are a common bycatch of potting, trapping, or net fishing. Large individuals can be caught by angles or harpooned. Measurable bones in the Esztergom material mostly originate from 30 - to 40 - $\mathrm{cm}$-long individuals or shorter. A single bone originated from a pike exceeding $83 \mathrm{~cm}$ in total length (Fig. 5b). Of the seven fourteenth century pike, three were small, reflecting the sizes of non-measurable fragments. Bones of such small individuals made up 41.4 and $42.2 \%$ of pike bones in the fourteenth and fifteenth century deposits respectively $\left(\chi^{2}=0.020, \mathrm{df}=1, \mathrm{P}=0.924\right)$.

Size may be reflected in the AD 1489 account book of Ippolito d'Este. Although pike was highly appreciated and its liver was considered a delicacy (Csánki 1897), it was purchased very cheaply by the archbishopric. While six carps cost 70 denarii, 12 pikes were bought only for 29 denarii: a carp
Fig. 4 Estimated total lengths of sterlet, pike, and carp
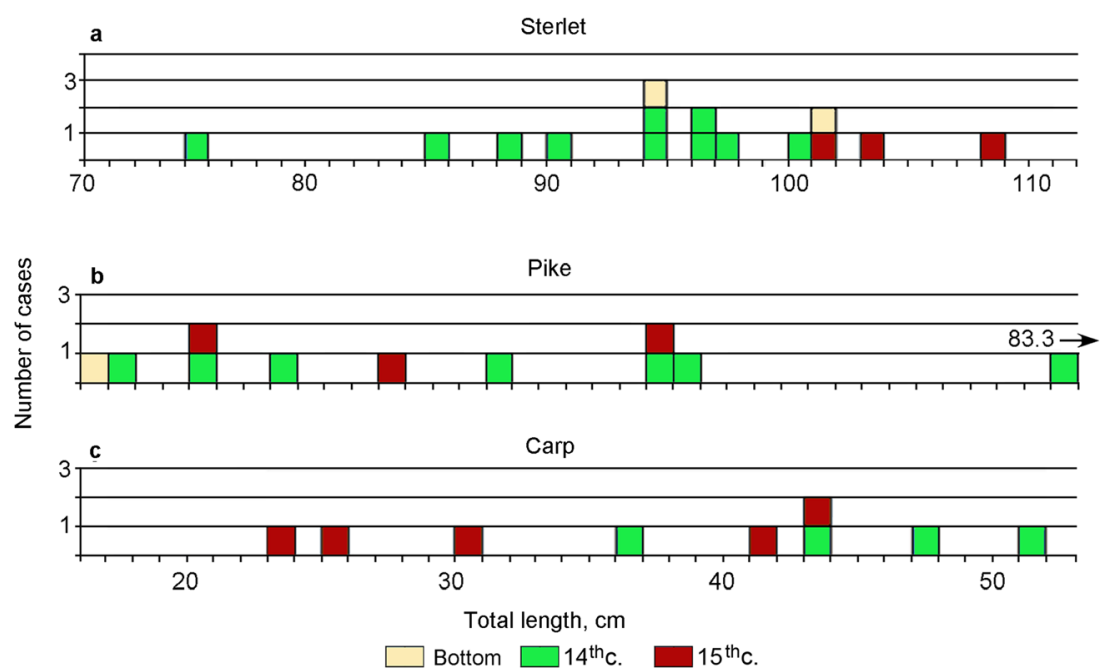


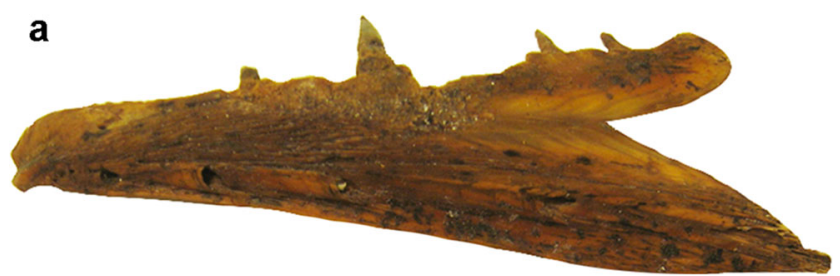

b
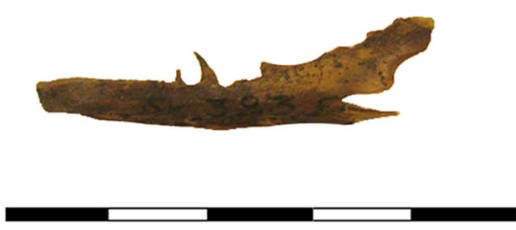

C

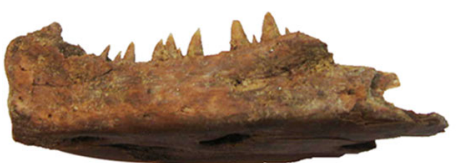

Fig. 5 Left dentalia of large (a) and small (b) pike, and adult pikeperch (c). Scale $5 \mathrm{~cm}$

thus costs five times more than a pike! Although this source mentions two "large carps", the size of the pike is not specified. A possible explanation is that the pikes were small as supported by the bone finds. Hoffmann (2020) notes that this size range parallels the minimum legal size in Bavarian and Austrian fishing regulations from around AD 1500.

\section{Cyprinids}

The NISP of remains in the carp fish family increased from 62.8 to $75.3 \%$. The proportion of identifiable carp remains also increased by half during this period. The same trend, in part, is visible in the increasing relative abundance of carp (and cyprinids in general) even in hand-collected assemblages from late/postmedieval sites in Hungary. The same tendency is evident in the contribution of cyprinids to medieval diets in the Vienna Basin (Galik et al. 2015).

Morphologically, carp fish species can be distinguished using only a few skeletal elements, especially the toothed lower pharyngeal bone (ceratobranchial). Fully grown carp may exceed $1 \mathrm{~m}$, being longer than adult bream (Abramis brama), crucian carp, tench (Tinca tinca), etc. (Berinkey 1966). Remains of large carp thus could be identified on the basis of size even in the case of less specific skeletal elements. Non-diagnostic bones of young carp, however, cannot be recognised among those of other small cyprinid species.

Two-thirds of the twelfth-sixteenth century fish remains from the castle of Gaiselberg in Lower Austria originated from carp (Spitzenberger 1983, 139). Wild carp, native to the Middle Danube Basin (Balon 1995), crossed the DanubeRhine watershed by the eleventh-twelfth century through the import of live fish to high-status secular and ecclesiastical centres (Hoffmann 1996). It became part of the ichthyofauna in France by the $1280 \mathrm{~s}$, but in Poland only by the $1530 \mathrm{~s}$ (Hoffmann 1999; Makowiecki 2008a). Several forms of domestic carp evolved in fish ponds (Schmelzl 1547), many of which reentered natural waters.

Carp bones in Esztergom originate from individuals measuring around $40 \mathrm{~cm}$ (Fig. 4c). No extremely large carp was identified. A small carp was comparable to an adult bream in size. These length estimates largely correspond to individuals harvested from fish ponds (Galik et al. 2015). Other species in the cyprinid family also vary between 20 and $60 \mathrm{~cm}$ in total length.

Fish in natural waters can be landed most successfully during spawning when many move near river banks. The spawning rush varies between species depending on water temperature, i.e. the concentration of dissolved oxygen of which carp and tench have especially low requirements $(0.7$ mg/l; Pénzes and Tölg 1977). On the basis of specific spawning seasons, the likely time of catch can be estimated (Pike-Tay et al. 2004). Cyprinids in this material represent the entire spring and early summer, interestingly reconfirming a note in the account books of Ippolito d'Este: at the beginning of spawning in April, the archbishopric's kitchen began buying basket loads of crucian carp together with other nonspecified white fish ("karas cum ... aliis albis piscibus"; Kuffart 2018).

\section{Percids}

Only a few bones of perch (Perca fluviatilis) and pikeperch (Sander lucioperca) were identified. These fish prefer slowmoving, voluminous rivers and still waters rich in dissolved oxygen (2.0-3.0 mg/l; Pénzes and Tölg 1977). It may thus be presumed that individuals in the Esztergom assemblage were caught in the Danube. The total length of perch rarely exceeds $50 \mathrm{~cm}$. Adult pikeperch are 50 to $60 \mathrm{~cm}$ long, sometimes reaching $1 \mathrm{~m}$ (Fig. 5c).

\section{Catfish}

Catfish/wels is a highly adaptable aquatic carnivore (Berinkey 1966). Its late spawning (coinciding with that of tench) shows that it is less sensitive to oxygen content. The popular Hungarian name of catfish, "peasant gobbler" (Gozmány 1979), indicates that it may grow $2.5 \mathrm{~m}$ long, weighing 120 $\mathrm{kg}$. The third century AD Roman fort of Iža (Slovakia; $40 \mathrm{~km}$ upstream from Esztergom) yielded a vertebra whose mediolateral diameter was $42.2 \mathrm{~mm}$, indicative of an individual exceeding $2.5 \mathrm{~m}$ (Hensel 2004). Notably, the village next to Iža is called Harčáš, meaning "rich in catfish" in Hungarian. We are therefore curious that only a few bones of this large species were recovered. Even those originated from small individuals - as was also observed with pike. Two complete 
cleithra yielded total lengths of $34.1 \mathrm{~cm}$ and $39.9 \mathrm{~cm}$. Catfish of this size may also have been bycatch of carp net fishing.

\section{Terrestrial meat sources}

Aside from livestock of greatest importance, the high diversity of birds and the marked presence of hare are noteworthy. The quantitative contribution by these taxa was small, but they represent high-quality tender meat. Some were exempt from fasting regulations. The proportions between various categories (boldface in Table 2) show no difference between the fourteenth and fifteenth centuries $\left(\chi^{2}=2.311\right.$, df $=3, \mathrm{P}=$ $0.510)$.

Domestic hen (Gallus domesticus) and pigeon (Columbidae) were likely kept at or near the site. The meat and eggs of chicken could be consumed during Lent (Serjeantson 2001). The anatomical and age distributions of pigeon bones (Gál 2020) support the hypothesis that the domestic form was kept at rural, urban, and high-status settlements alike (Bökönyi 1974; Biller 2014; Lyublyanovics 2018). The bones of domestic goose and duck (Anatidae) cannot be distinguished from those of their wild forms (Gál 2020).

Table 2 The diachronic distribution of bird and hare remains. The sums of major categories are indicated in bold print

\begin{tabular}{|c|c|c|c|c|}
\hline Species & Bottom & Fourteenth c. & Fifteenth c. & Total \\
\hline Domestic hen (Gallus domesticus L. 1758) & 95 & 1368 & 612 & 2075 \\
\hline Domestic pigeon (Columba domestica L. 1758) & & 17 & 5 & 22 \\
\hline Domestic bird & 95 & 1385 & 617 & 2097 \\
\hline Domestic/grey lag goose (Anser domesticus/A. anser L. 1758) & & 67 & 33 & 100 \\
\hline Domestic duck/mallard (Anas domesticalA. platyrrhynchos L. 1758) & & 10 & 7 & 17 \\
\hline Wild or domestic bird & & 77 & 40 & 117 \\
\hline Glossy ibis (Plegadis falcinellus L., 1766) & & & 1 & 1 \\
\hline Eurasian teal (Anas crecca L. 1758) & & & 1 & 1 \\
\hline Gadwall (Anas strepera L. 1758) & & & 2 & 2 \\
\hline Garganey (Anas querquedula L. 1758) & & & 1 & 1 \\
\hline Tufted duck (Aythya fuligula L. 1758) & & 1 & & 1 \\
\hline Goshawk (Accipiter gentilis L. 1758) & & & 1 & 1 \\
\hline Eurasian sparrow hawk (A. nisus L. 1758) & & & 1 & 1 \\
\hline Partridge (Perdix perdix L. 1758) & 6 & 170 & 69 & 245 \\
\hline Quail (Coturnix coturnix L. 1758) & & 1 & 3 & 4 \\
\hline Common pheasant (Phasianus colchicus L. 1758) & & 6 & 3 & 9 \\
\hline Little bustard (Tetrax tetrax L. 1758) & & 1 & & 1 \\
\hline Fieldfare (Turdus pilaris L. 1758) & & 6 & 3 & 9 \\
\hline Common blackbird (Turdus merula L. 1758) & & 3 & & 3 \\
\hline Redwing (Turdus iliacus L. 1758) & & 2 & & 2 \\
\hline Song thrush (Turdus philomelos L. 1758) & & 4 & 4 & 8 \\
\hline Mistle thrush (Turdus viscivorus L. 1758) & 1 & 8 & 2 & 11 \\
\hline Starling (Sturnus vulgaris L. 1758) & & 1 & & 1 \\
\hline Eurasian jay (Garrulus glandarius L. 1758) & & 1 & & 1 \\
\hline Eurasian nutcracker (Nucifraga caryocatactes L. 1758) & & 1 & & 1 \\
\hline Rook (Corvus frugilegus L. 1758) & & & 3 & 3 \\
\hline Wild bird & 7 & 205 & 94 & 306 \\
\hline Brown hare (Lepus europaeus Pall. 1778) & 5 & 70 & 41 & 111 \\
\hline Total NISP & 107 & 1737 & 792 & 2636 \\
\hline Non-identifiable small mammal & 2 & 5 & 5 & 12 \\
\hline Non-identifiable fowl (Galliformes sp. indet.) & 6 & 29 & 17 & 52 \\
\hline Non-identifiable songbird (Passeriformes sp. indet.) & & 7 & 4 & 11 \\
\hline Non-identifiable bird (Aves sp. indet.) & 2 & 85 & 40 & 127 \\
\hline Total & 117 & 1863 & 858 & 2838 \\
\hline
\end{tabular}


Table 3 The ratios between thoracic and caudal vertebrae in pike and cyprinids. The sums of major categories are indicated in bold print

\begin{tabular}{|c|c|c|c|c|}
\hline & $\begin{array}{l}\text { Thoracic } \\
\text { Vertebrae, } n\end{array}$ & Caudal & Thoracic/caudal ratio & Natural ratio \\
\hline \multicolumn{5}{|c|}{ Fourteenth century } \\
\hline Pike & 17 & 9 & 1.9 & $\approx 2$ \\
\hline Carp & 8 & 3 & 2.7 & $\approx 1$ \\
\hline Small cyprinid & 31 & 48 & 0.6 & $\approx 1$ \\
\hline Total & 56 & 60 & (0.9) & \\
\hline \multicolumn{5}{|l|}{ Fifteenth century } \\
\hline Pike & 11 & 2 & 5.5 & $\approx 2$ \\
\hline Carp & 12 & 9 & 1.3 & $\approx 1$ \\
\hline Small cyprinid & 14 & 16 & 0.9 & $\approx 1$ \\
\hline Total & 37 & 27 & (1.3) & \\
\hline
\end{tabular}

Partridge (Perdix perdix) was the most common wild fowl consumed in medieval Hungary (Bartosiewicz et al. 2018). The extinct black-necked pheasant subspecies (Phasianus colchicus colchicus) is considered to have been autochthonous to southeastern Bulgaria (Boev 1997) as it seems to have had a continuous range in Turkey from the Sea of Marmara to the edge of the Balkans (Gürler et al. 2012). In the Carpathian Basin, however, prehistoric evidence for pheasant is missing (Kordos 2006). Although several references (e.g. Kleiner 1940; Kordos 2006) indicate that this bird was first introduced to Europe by the Romans, osteological evidence for this species is so far absent from Roman period Pannonia (present-day western Hungary). The oldest pheasant find (a tarsometatarsus) was identified in the eighth-ninth century layers of Zalavár Castle (Jánossy 1985, p. 76). It is hard to decide whether this specimen is attributable to import before the second introduction of pheasant in the Middle Ages (as the continuous evidence from the thirteenth century onwards would suggest; Matolcsi 1981), or it may have belonged to the wild avifauna after the collapse of the Roman Empire. By the fourteenth-fifteenth century, remains of pheasant were found at several settlements (Bökönyi 1974; Matolcsi 1982). Pheasants may have equally been hunted or farmed as luxury birds (Kordos 2006).

The question arises whether the leporine bones originated from domestic rabbit rather than brown hare: bones of the two are difficult to distinguish (Callou 1997). However, the few diagnostic elements and relatively large size of remains point to hare; thus, they have been listed as such in Table 2 .

\section{Fish butchering}

Skeletal elements of fish grouped by major body regions showed no significant difference between the two main periods (Fig. 6; $\chi^{2}=3.848, \mathrm{df}=5, \mathrm{P}=0.572$ ). The number of vertebrae ranges between 61 and 64 in pike (Kiss 2000), twothirds of which represent the meat-rich thoracic region.
Cyprinids have only 36-37 vertebrae, but the number of thoracic and caudal vertebrae is roughly the same (Kiss 2000). Comparing these differences between the two species (Table 3), it is clear that the number of vertebrae found reflects the natural ratio in a single individual only in the group of small cyprinids. In the case of (small) pike, meaty parts dominated by the fifteenth century, while carp was represented by the meat-rich thoracic region in both periods. Cut marks on small fish bones tend to be relatively rare.

Unfortunately, due to age-related osteoporosis, acipenserid vertebrae are rarely found and dermal scutes cannot be used in accurately assessing the quantity of meat. Meaty parts (without the head and offal) of fully grown sturgeons reach $70 \%$ of live weight (Bartosiewicz and Bonsall 2008). The eggs (caviar) harvested from females were highly appreciated in medieval Hungary (Kubinyi 2002) adding to the value of these fish.

A compact first pectoral fin ray of great sturgeon found at the bottom of the deposit was hacked, showing how the head had been separated from the trunk (Fig. 7). It is a sign of primary butchery (prior to cooking), suggesting that fresh rather than salted sturgeon was consumed. The clear hacking mark is a reminder that Sigismund von Luxemburg, King of Hungary, gave permission to urban butchers to sell large fish at their stands in AD 1405: their partitioning required tools and skills identical to those used in partitioning livestock (Kenyeres et al. 2008).

The relative absence of the remains of large sturgeon or catfish in Esztergom does not necessarily mean that these large fish were rarely eaten. It cannot be ruled out that the large carcasses of such individuals were not delivered whole to the archbishop's kitchen. For example, on the 24th of February AD 1520, "the tender meat of a great sturgeon and a pike" was served (in addition to 100 small fish) to him in Buda (Zolnay 1977); although the archbishop died in September that year in Ferrara, there are accounts regarding 
$\mathrm{NISP}=691 \quad \mathrm{NISP}=363$

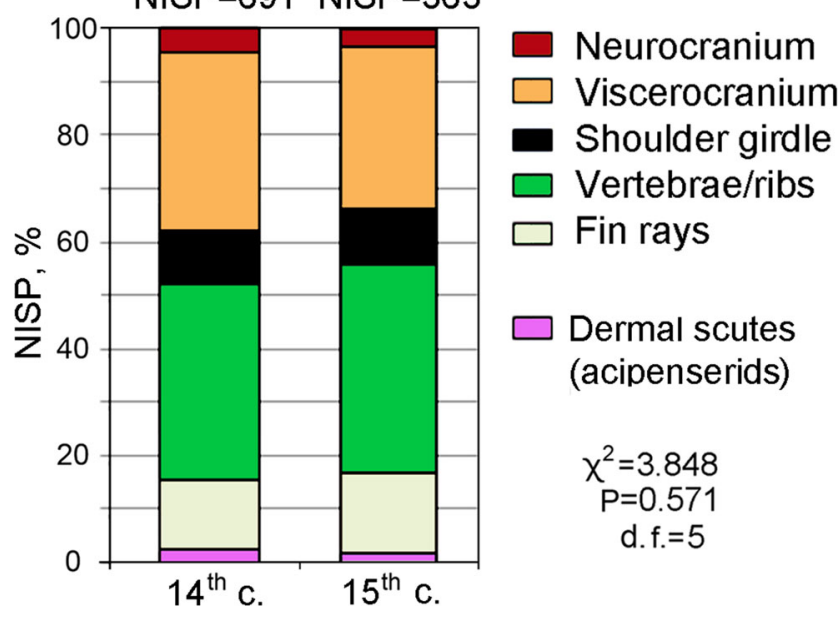

Fig. 6 Gross anatomical distributions of the fish remains in the main periods

his expenses in Hungary in the "Libro di spese durante un suo viaggio in Ungheria" (Kuffart 2018).

\section{Discussion}

The most outstanding features of the assemblage from the archbishop's kitchen were the significant diachronic increase in cyprinid remains and the presence of small fish and wild birds. These animals markedly differ from ordinary livestock both in terms of procurement and consumption.

The small size of fish is also remarkable. Reconstructed total lengths shown in Fig. 4 are relatively short in a broader comparison. In sharp contrast to Esztergom, the majority of hand-collected pike bones from the largely contemporaneous Vilnius Castle, Lithuania, included individuals measuring between 60 and $80 \mathrm{~cm}$ in length. Bream and tench were 45 to $50 \mathrm{~cm}$ long, and one cyprinid vertebra came from a $100-\mathrm{cm}-$ long fish. An operculare belonged to an 80- to 90-cm-long carp (Piličiauskienè and Blaževičius 2019). Dry-screened fish remains from the Zobor Monastery, Slovakia, also confirm the

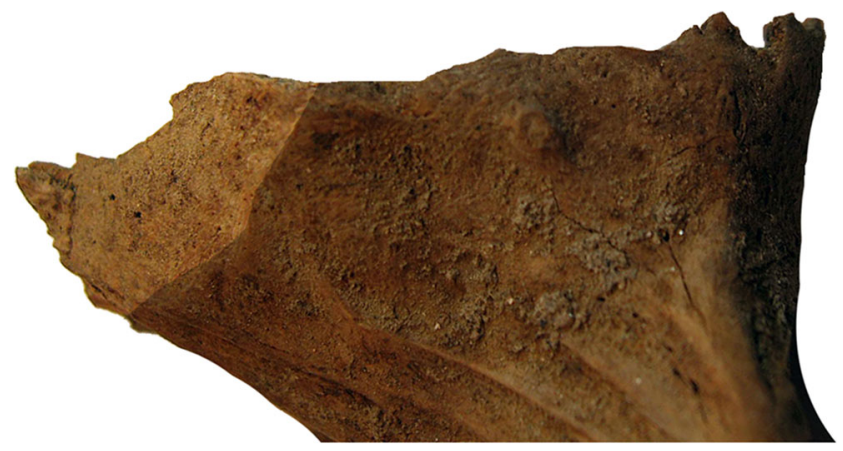

Fig. 7 Hack mark on the pectoral fin ray of great sturgeon (bottom layer). Scale $3 \mathrm{~cm}$ consumption of much larger, 90- to 110-cm-long individuals of both pike and carp (Bielichová et al. 2019).

\section{Procurement}

Fishing in natural waters is most rewarding during the spring and summer. Fish could thus be easily procured for fasting during the 40 days of Lent and lesser holidays such as the June days of John the Baptist or Peter and Paul. Supplies during the winter half of the year were scarcer (Makowiecki 2008a) unless fish were farmed in ponds. In medieval England, landscape features and documentary sources are indicative of pond fishing among a small section of elite society, to whom freshwater species played an important role in feast and fast alike as well as in gift exchange. However, marine species had dominated the fish supply from the late tenth century (Locker 2018). In land-locked Central Europe, native forms of medieval farmed fish could be caught in the wild since prehistory. With the exception of anadromous acipenserids, the archbishop's kitchen refuse contained such species. Distinguishing between their wild/riverine and farmed/pond forms is difficult.

Damming streams for fish ponds has been documented since the eleventh century (Hoffmann 2000). In Hungary, 3000-4000 fish ponds may have operated during the eleventh-thirteenth century (Pesty 1867). By AD 1450 1550 , water management changed the landscape in Bohemia: rivers were diverted to create extensive lake surfaces (Andreska 1984). Archaeological evidence of damming the Búbánat valley, merely $6 \mathrm{~km}$ east of Esztergom, suggests that there was a pond during the thirteenth century in connection with the Ákospalota residence acquired by the archbishopric in the fourteenth century (Horváth et al. 1979).

Medieval pike samples showing elevated $\delta^{15} \mathrm{~N}$ values from Altenburg Castle in Switzerland (Häberle and Hüster Plogmann 2019) were indicative of a nutrient-rich habitat, possibly a pond. But in the absence of systematic stable isotope studies, a zoological distinction between riverine and farmed origins can be at best based on size variability.

Advanced ponds became specialised by age cohorts, designated for spawning, hatchlings, and fattening. Aside from carp, young pikes were kept to control small cyprinids competing with carp and even excess offspring by the carp itself, mimicking the natural balance of fish faunas (Bourquelot 1863). By the fourteenth century, pike was a common bycatch of carp production. Rarely, valuable pikeperch and catfish were also kept in ponds. Although small pike and catfish fit within the population structure of pond habitats, the presence of fully grown predatory fish would have been detrimental to carp farming. Fifteenth century documents in Hungary reveal that a separate pond was built for highly valued pike in Tárkány, one of the estates in the Eger diocese (Kerezsy 1910). 
The scarcity of sturgeons, the only indubitably riverine species at this site, is curious as most known remains originate from high-status settlements along the 72-km-long section of the Danube between Esztergom and Buda (Bartosiewicz and Bonsall 2008). Large acipenserids at ecclesiastic centres are even concentrated in the fourteenth and fifteenth centuries, while their remains from secular settlements represent a broad time interval (Bartosiewicz 2018). The archbishopric's AD 1489 kitchen account books do not mention the purchase of acipenserids: the few bones may originate from sturgeons caught in rivers crossing their own estates. However, the paucity of sturgeon remains in our archaeological assemblage may be misleading. Although medieval overfishing of sturgeons has been proposed in the Baltic zone (Benecke 1986; Makowiecki 2008b), contemporaneous documentary sources do not refer to this problem in Hungary, rather the abundance of sturgeon is emphasised. Accompanying the bishop of Passau, János Kanizsai, the then archbishop of Esztergom, visited a sturgeon catching site around AD 1411-1412. They saw ten sturgeons are being landed within an hour and a half (Zolnay 1977). At the end of the fifteenth century, the archbishopric sold quantities of salted sturgeon in Kolárovo and Nesvady (Nyáry 1870). Large-scale commercial operations included the butchery, salting, and packaging of sturgeons at the site of landing (Bartosiewicz and Bonsall 2008). Thus, transportation loss (the early discard of bones of no culinary value) seems more likely in the case of large fish than overfishing. It was only around the mid-nineteenth century that overexploitation along with increasing pollution and intensifying boat traffic began to take its toll on Danube sturgeon stocks (Bartosiewicz et al. 2008).

Wild birds and hare must have been easily available in the variegated ecotone (plain, floodplain, and hills) in which Esztergom is located. While the domestic origins of pigeons could be estimated using age distributions as a proxy for husbandry, goose and duck remains did not show such patterns. Unfortunately, the bones of adult domestic goose and duck cannot be distinguished from those of their wild forms, which could be hunted (Gál 2020). In contrast to hunting large game, catching hare may have been less regulated and did not require special skills or weaponry. Similar to some birds, these grassland animals could be snared, caught in nets, or hunted using lurchers or raptors.

\section{Consumption}

The increasing contribution of small cyprinids to the Esztergom assemblage should not be underestimated. Although other small fish such as bullhead (Cottus gobio), weatherfish (Misgurnus fossilis), and river lamprey (Lampetra fluviatilis) - regular entries in medieval cookbooks - are yet to be identified from medieval Hungary (Galik et al. 2015), they are present in dry-screened assemblages from Germany and Switzerland (Heinrich 1995; Brombacher et al. 1998; Nussbaumer and Rehazek 2007).

The cookbook of Anna Bornemisza (Lakó 1983) is the oldest complete cookbook published in Hungarian. It is the AD 1680 adaptation of the AD 1581 cookbook of the Mainz elector (Rumpolt 1581) by János Keszei. It contains recipes for reflecting the tastes of rulers as well as their yearning for self-representation. The 39 fish species listed in the Bornemisza cookbook make up one-third of all animals mentioned. In terms of the most common species, proportions between freshwater fish recipes reflect the pattern seen in Esztergom. Fish potentially raised in ponds (sterlet, carp, and small cyprinids: 773 bone finds vs. 93 recipes) show comparable proportions in the food refuse and among recipes (Fig. 8). King Matthias and the Bavarian Prince visited Ippolito d'Este in April AD 1489. Although it possessed extensive fishing grounds, the archbishopric bought 400-400 carps and pikes (Nyáry 1872). This entry shows extreme fish consumption during feasts and underlines the immediate importance of carp and pike, well represented both in the found material and in the Bornemisza cookbook.

Although late medieval latrines in the Vienna Basin and in St. Pölten yielded quantities of herring (Clupea harengus) vertebrae (Galik et al. 2015), direct evidence of marine fish is unknown from medieval sites in Hungary. Small and fatty herring bones are notoriously prone to taphonomic loss, including possible autolysis as well as animal and human digestion (Jones 1986). Five herring recipes are included in Anna Bornemisza's cookbook. This work is, however, an almost direct translation from German. Nevertheless, salted herring seems to have been traded to the region: fragments of an oak barrel used in lining a late medieval well at the oppidum in Muhi (Grynaeus 2003) originated from Poland and could be indicative of long-distance herring trade reaching eastern Hungary (Lyublyanovics 2008). While herring is not mentioned in the Esztergom account books, 87 were recorded on the 25th of February AD 1520 at a feast in Buda along with

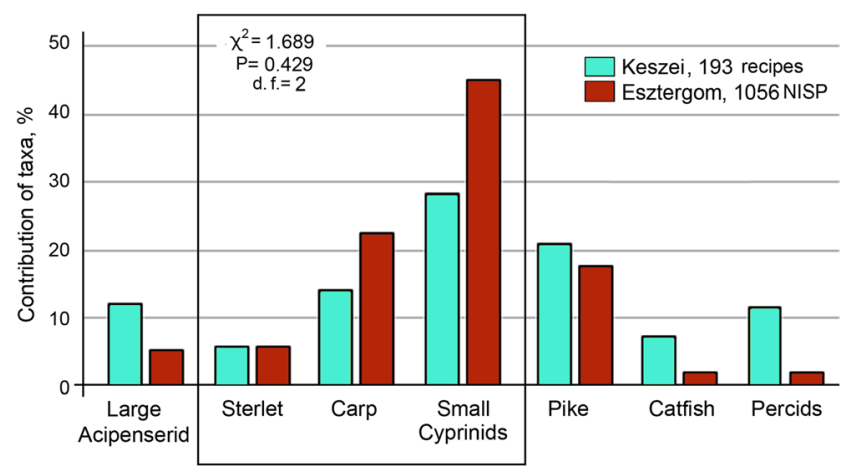

Fig. 8 The relative frequencies of major fish taxa in the cookbook of Anna Bornemisza by János Keszei and in the pooled fish bone assemblage from Esztergom 
both salted and fresh sturgeon meat, sturgeon caviar, 15 pikes, and ten non-specified marine fish (Zolnay 1977).

Only half of the 42 known hand-collected medieval assemblages yielded bones of small birds ( 13 species/ 5 orders) in Hungary. Thrushes seem to have been popular, represented by five species at four sites: a village, a town, and two elite centres including Esztergom (Gál 2020). Partridge and thrushes (Turdus sp.) regularly contributed to medieval upper-class diets as shown by high-status recipes (Albarella and Thomas 2002; Baker 2010). The Bornemisza cookbook listed 15 recipes for partridge and mistle thrush each. Other recipes included quail (Coturnix coturnix, 19); hazel grouse (Tetrastes bonasia, 12); pigeon (20); and turtle dove (Streptopelia turtur, 8); as well as hoopoe (Upupa epops); cuckoo (Cuculus canorus); common tern (Sterna hirundo); martin (Hirundinidae); swallow; starling (Sturnus vulgaris); lark (Alaudidae); nightingale (Luscinia megarhynchos); and wren (Troglodytes troglodytes) (Gál 2020). The practice of trapping and consuming thrushes was recorded across medieval Europe (Magnus 1555), especially in winter when they "have grown fat on juniper berries and myrtle" (Cerruti 1984). Long after his decade-long tenure as archbishop of Esztergom, Ippolito d'Este had seven fieldfares (Turdus pilaris) served at a dinner he hosted in Buda on the 19th of February AD 1520 (Zolnay 1977). Eating fieldfare was even allowed during Lent (Lakó 1983). Domestic pigeons could complement the range of small wild birds regardless of season.

Rabbit (Oryctolagus cuniculus) is not native to Hungary and its domestic version was distributed in Central Europe by religious orders arriving from France (Irving-Pease et al. 2018). Its earliest remains are known from the sixteenth to seventeenth century layers of Visegrád-Salamon torony (Bökönyi 1974). Rumpolt (1581) illustrated "sea hare" (the name referring to the Mediterranean) or Küniglein using the same image as a rabbit (Kaninchen). Both German names mean rabbit. These animals were merged into 11 recipes in the Bornemisza cookbook. Brown hare, on the other hand, was represented by 20 recipes, among those of other common game (Lakó 1983).

\section{Conclusions}

Given the widespread romantic topoi concerning medieval luxury food, meat diets in the kitchen of the Esztergom archbishopric seem surprisingly modest, based on ordinary livestock. Convincing evidence of regular hunting is absent, and mammalian and avian remains show no diachronic change during the fourteenth- fifteenth century. Thanks to screening, fish, small birds, and hare could be studied as colouring elements in this humble, monotonous diet.

A significant increase in fish consumption was largely driven by a major contribution of carp fish in the fifteenth century, while the proportion of luxurious large acipenserids and carnivorous fish declined. Contemporaneous financial records suggest that while the archbishop's kitchen increasingly relied on purchasing carp fish, sturgeons were a commodity the archbishopric rather sold.

A reconstruction of total lengths was indicative of small individuals, probably landed through net fishing. Since sterlet, cyprinids, and pike are native to the Danube in Hungary, it is impossible to determine whether these fish were caught in the river (e.g. during spring and early summer floods) or were farmed. The absence of large individuals is remarkable in all fish species: while the lack of screening could explain the absence of small fish, if large individuals were consumed, they should be visible in the screened Esztergom assemblage.

Comparisons with written sources confirm the importance of common, rather than luxury fish at this site. Pike bought at suppressed prices by the archbishopric reflects the small size of individuals observed in the deposits. References to seasonality in fish and birds consumed at the site are also reflected in several account book entries.

The absence of luxury food items raises the question whether the refuse represents the diet of the kitchen's personnel, rather than feasting by the archbishop and his entourage, even if a few references in the archbishopric's late fifteenth century account books are consonant with diachronic patterns observed in the taxonomic composition and size distribution of fish remains. Research on Anglo-Saxon England has directed attention to "background noise" in the interpretation of status based on meat consumption, created by the fact that low-ranking people regularly formed part of the communities at ecclesiastic and other high-status centres (Dobney and Jaques 2002). The possibility of composite food refuse left behind by people of different social standings is supported by complexities of architectural history in Esztergom suggesting that the archbishop's kitchen may have been located above that of the personnel employed at his kitchen (Benkö et al. 2021).

Acknowledgements Excavations at Esztergom-Várhegy-Kőbánya were carried out by Balázs Major of the Péter Pázmány Catholic University and his team in 2014-2016. Our research formed part of the Grant NKFI K112318 supported by the National Research, Development and Innovation Office of Hungary. Kind support by Elek Benkő, leader of the project, is acknowledged here for having invited us to study the zooarchaeological material. Eszter L. Kis Szabó, Róbert Lóki, Krisztina Orosz, and Csilla Zatykó provided valuable advice during the archaeological interpretation of the results. Special thanks are due to two anonymous reviewers whose insightful comments and corrections significantly contributed to improving our manuscript.

Availability of data and material Not applicable. Code availability Not applicable.

Author contribution Both authors contributed to the study concept and design. Research on fish was performed by LB, and studies of game were 
conducted by EG. The first draft was presented on the 26th of August 2019 at the 20th meeting of the ICAZ Fish Remains Working Group (Portland State University, USA). The manuscript was approved by both authors.

Funding Open access funding provided by Stockholm University. This study was funded by the National Research, Development and Innovation Office of Hungary.

\section{Declarations}

Conflict of interest The authors declare no competing interests.

Open Access This article is licensed under a Creative Commons Attribution 4.0 International License, which permits use, sharing, adaptation, distribution and reproduction in any medium or format, as long as you give appropriate credit to the original author(s) and the source, provide a link to the Creative Commons licence, and indicate if changes were made. The images or other third party material in this article are included in the article's Creative Commons licence, unless indicated otherwise in a credit line to the material. If material is not included in the article's Creative Commons licence and your intended use is not permitted by statutory regulation or exceeds the permitted use, you will need to obtain permission directly from the copyright holder. To view a copy of this licence, visit http://creativecommons.org/licenses/by/4.0/.

\section{References}

Albarella U, Thomas R (2002) They dined on crane: bird consumption, wild fowling and status in medieval England. Acta Zool Cracov 45: 23-38

Andreska J (1984) Development of fish-pond culture in Bohemia. In: Gunda B (ed) The fishing culture of the world 2. Akadémiai Kiadó, Budapest, pp 77-83

Baker P (2010) Procurement, presentation and consumption of domestic and wildfowl at Windsor Castle, England in the 12th-14th c. In: Prummel W, Zeiler JT, Brinkhuizen DC (eds) Proceedings of the 6th meeting of the ICAZ Bird Working Group in Groningen. Barkhuis, Groningen, pp 57-69

Balon EK (1995) Origin and domestication of the wild carp, Cyprinus carpio. Aquaculture 129:3-48

Bartosiewicz L (1990) Osteometrical studies on the skeleton of pike (Esox lucius L. 1758). Aquac Hung VI:25-34

Bartosiewicz L (2018) "Kleine Fische, gute Fische". In: Mérai D, Drosztmér Á, Lyublyanovics K, Rasson J, Papp Reed Zs, Vadas A, Zatykó Cs (eds) Genius loci. Laszlovszky 60. Archaeolingua Foundation, Budapest, pp 121-125

Bartosiewicz L, Bonsall C (2008) Complementary taphonomies: medieval sturgeons from Hungary. In: Béarez P, Grouard S, Clavel B (eds) Archéologie du Poisson. Éditions APDCA, Antibes, pp 35-45

Bartosiewicz L, Gál E (2007) Sample size and taxonomic richness in mammalian and avian bone assemblages from archaeological sites. Archeometriai Mühely 2007(1):37-44

Bartosiewicz L, Takács I (1997) Osteomorphological studies on the great sturgeon (Huso huso Brandt). Archaeofauna 6:9-16

Bartosiewicz L, Bonsall C, Şişu V (2008) Sturgeon fishing along the Middle and Lower Danube. In: Bonsall C, Boroneanț V, Radovanović I (eds) The Iron Gates in prehistory, vol 1893. New perspectives. British Archaeological Reports, International Series, pp 39-54

Bartosiewicz L, Biller AZ, Csippán P, Daróczi-Szabó L, Daróczi-Szabó M, Gál E, Kováts I, Lyublyanovics K, Nyerges ÉÁ (2018) Animal exploitation in medieval Hungary. In: Laszlovszky J, Nagy B, Szabó
P, Vadas A (eds) The economy of medieval Hungary. Brill, Leiden, pp 113-165

Bél M (1764) Tractatus de rustica Hungarorum: a magyarországi halakról és azok halászatáról. Vízügyi Történeti Füzetek, Budapest

Benecke N (1986) Some remarks on sturgeon fishing in the southern Baltic region in medieval times. In: Brinkhuizen DC, Clason AT (eds) Fish and archaeology. Studies in osteometry, taphonomy, seasonality and fishing methods. British Archaeological Reports International Series 294, Oxford, pp 9-17

Benkő E, Horváth I, Végh A (2021) Az esztergomi várhegy középkori érseki palotájának konyhaleletei (Archaeological finds from the medieval kitchen of the archbishopric palace in Esztergomi-Várhegy). In: Benkő E, Cs Z (eds) A Kárpát-medence környezettörténete a középkorban és a kora újkorban (Environmental history of the medieval and early modern Carpathian Basin). Archaeolingua, Budapest, pp 1-10

Berinkey L (1966) Halak - Pisces. Akadémiai Kiadó, Budapest

Bielichová Z, Samuel M, Hensel K (2019) Ryby a pôst v Zoborskom kláštore pri Nitrevo svetle archeozoologických dokladov (Fish and fasting in the Zobor Monastery in Nitra in the light of archaeozoological evidence). Študijné Zvesti Archeologického Ústavu SAV 65:133-177

Biller AZs (2014) Solt-Tételhegy feltárásának állatcsont leletei (The animal bones from the excavation at Solt-Tételhegy). In: Somogyvári Á, Szentpéteri J, V. Székely Gy (eds) Településtörténeti kutatások. Solt-Tételhegy, Kiskunfélegyháza, Amler-bánya (Settlement studies. Solt-Tételhegy, Kiskunfélegyháza, Amler-bánya). Archaeologia Cumanica 3:205-224

Boev Z (1997) Wild galliform and gruiform birds (Aves, Galliformes and Gruiformes) in the archaeological record of Bulgaria. Int $\mathrm{J}$ Osteoarchaeol 7:430-439

Bökönyi S (1974) History of domestic mammals in Central and Eastern Europe. Akadémiai Kiadó, Budapest

Bourquelot $\mathrm{F}$ (1863) Fragments de comptes du XIIIe siècle. Bibliothèque de l'école des chartes 24:51-79

Brinkhuizen DC (1986) Features observed on the skeletons of some recent European Acipenseridae: their importance for the study of excavated remains of sturgeon. In: Brinkhuizen DC, Clason AT (eds) Fish and archaeology. British Archaeological Reports International Series 294:18-33

Brombacher C, Helmig G, Hüster-Plogmann H, Klee M, Rentzel P, Rodel S, Veszeli M (1998) ...und was davon übrig bleibt Untersuchungen an einem Latrinenschacht an der Bäumleingasse 14 (1992/20). Jahresberichte der Archäologischen Bodenforschung des Kantons Basel-Stadt:93-131

Callou C (1997) Diagnose différentielle des principaux éléments squelettiques du lapin (genre oryctolagus) et du lièvre (genre lepus) en Europe occidentale. Fiches d'ostéologie animale pour l'archéologie, Série B 8

Cerruti (1984) The four seasons of the House of Cerruti. (Translated by J. Spencer). Facts on File Inc., New York.

Csánki D (1897) Magyarország történeti földrajza a Hunyadiak korában III. Magyar Tudományos Akadémia, Budapest

Desse-Berset N (1994) Sturgeons of the Rhône in Arles (6th-2nd century BC). In: Van Neer W (ed) Fish exploitation in the past. Koninklijk Museum voor Midden-Afrika, Annalen, Zoologische Wetenschappen 274:81-90

Dobney K, Jaques D (2002) Avian signatures for identity and status in Anglo-Saxon England. Acta Zool Cracov 45(special issue):7-21

Gál E (2020) Remains of small domestic and game birds from medieval sites in Hungary. Quat Int 543:99-107

Gál E (2021) Zooarchaeological analysis of the bishopric kitchen waste found at Esztergom-Castle Hill. Antaeus 37 (in press)

Galik A, Haidvogl G, Bartosiewicz L, Guti G, Jungwirth M (2015) Fish remains as a source to reconstruct long-term changes of fish 
communities in the Austrian and Hungarian Danube. Aquat Sci 77: 373-388

Gozmány L (1979) Vocabularium nominum animalium Europae septem linguis redactum. Akadémiai Kiadó, Budapest

Grynaeus A (2003) Die Brunnen im Oppidum Muhi. Anteus 26:255-264

Gürler AT, Bölükbaș CS, Pekmezci GZ, Umur S, Açıcı M (2012) Samsun'da Sülünlerde (Phasianus colchicus) Nekropsi ve Dışk1 Bakısında Saptanan Helmintler. Türk Parazitol Derg 36:222-227

Häberle S, Hüster Plogmann H (2019) Fish exploitation in medieval and early modern Switzerland: evidence from the ichthyoarchaeological record and historical sources. Int J Osteoarchaeol 29:420-431

Heinrich D (1995) Untersuchungen an Fischresten aus Kloaken des 17. Jahrhunderts in Höxter sowie Bemerkungen den dort geborgenen Knochen von Froschlurchen Ausgrabungen und Funde in Westfalen-Lippe:381-398

Heinrich D (2012/13) Bemerkungen zu Fischfunden aus einer Siedlungsgrube der späten Bronze- und der frühen Eisenzeit bei Wennungen, Burgenlandkreis, Sachsen-Anhalt. Offa 69(70):125137

Hensel K (2004) Find of a capital wels catfish Silurus glanis (Actinopterygii: Siluridae) in excavations of a Roman military fort in Southern Slovakia. Biologia 59:191-203

Hoffmann RC (1996) Economic development and aquatic ecosystems in medieval Europe. Am Hist Rev 101(3):631-669

Hoffmann RC (1997) Fishers' Craft \& Lettered Art. Tracts on fishing from the end of the Middle Ages. The University of Toronto Press, Toronto

Hoffmann RC (1999) Fish and man: changing relations in medieval Central Europe. Beiträge zur Mittelalterarchäologie in Österreich 15:187-195

Hoffmann RC (2000) Medieval fishing. In: Squatriti P (ed) Working with water in medieval Europe: technology and resource use. Brill, Leiden, pp 331-393

Hoffmann RC (2020) Chapter 5. Fisheries regulations in late medieval Europe: authorities, concerns, measures. In: Dowling AP, Keyser R (eds) Conservation's roots: managing for sustainability in preindustrial Europe, 1100-1800. Environments in History - International Perspectives series. Berghahn, New York, pp 125-153

Horváth I, Torma I, Kelemen HM (1979) Magyarország régészeti topográfiája 5. Akadémiai Kiadó, Budapest

Irving-Pease EK, Laurent AF, Sykes N, Callou C, Larson G (2018) Rabbits and the specious origins of domestication. Trends Ecol Evol 33(3):149-152

Jánossy D (1985) Wildvogelreste aus archäologischen Grabungen in Ungarn (Neolithicum bis Mittelalter). Fragmenta Mineralogica et Palaeontologica 12:67-103

Jones AKG (1986) Fish bone survival in the digestive systems of pig, dog and man: some experiments. In: Brinkhuizen DC, Clason AT (eds) Fish and archaeology. Studies in osteometry, taphonomy, seasonality and fishing methods. British Archaeological Reports International Series 294, Oxford, pp 53-61

Kenyeres I, Spekner E, Szende K (2008) A budai német mészárosok középkori céhkönyve (1496) 1500-1529 (1538, 1695). In: Kenyeres I (ed) A budai mészárosok középkori céhkönyve és kiváltságlevelei. Források Budapest közép- és kora újkori történetéhez 1, Budapest

Kerezsy J (1910) Bakócz Tamás egri püspök udvartartása és egyázmegyéje. Művelődestörténeti Értekezések 39. Loydl Testvérek könyvnyomdája, Erzsébetváros

Kiss I (2000) Biológiai alapismeretek. In: Horváth L (ed) Halbiológia és haltenyésztés. Mezőgazda Kiadó, Budapest, pp 17-68

Kleiner E (1940) Hazánk fácánállománya és a természetvédelem. Természettudományi Közlöny 72(9):328-333

Kordos L (2006) Évezredek bizonyítékai - a fácánok kalandos históriája. Magyar Vadászlap 2006 március:170-171
Kubinyi A (2002) Főúri étrend tábori körülmények között 1521-ben. In: Fodor P, Pálffy G, Tóth IG (eds) Tanulmányok Szakály Ferenc emlékére. MTA TKI, Budapest, pp 249-261

Kuffart H (2018) Modenában örzött esztergomi számadáskönyvek és az esztergomi érsekség udvartartása. Pázmány Péter Catholic University, Budapest, $\mathrm{PhD}$ Dissertation

Lakó E (1983) Bornemisza Anna szakácskönyve 1680-ból. Kriterion, Bukarest

Libois RM, Hallet-Libois C (1988) Éléments pour l'identification des restes crâniens des poissons dulçaquicoles de Belgique et du nord de la France. II. Cypriniformes. Fiches d'ostéologie animale pour l'archéologie, Série A 4

Locker A (2018) Freshwater fish in England: a social and cultural history of coarse fish from prehistory to the present day. Oxbow Books, Oxford-Havertown, PA

Lyublyanovics K (2008) Before the cattle trade. Animals and people in Muhi, a medieval Hungarian village. MA Thesis, Central European University, Budapest

Lyublyanovics K (2018) New home, new herds. Cuman integration and animal husbandry in medieval Hungary from an archaeozoological perspective. Archaeological Heritage Series 10, Oxford

Magnus O (1555) Description of the northern peoples, Rome 1555 (Vol. 3) (Transl. Foote P, 1998). The Hakluyt Society, London

Makowiecki D (2008a) Exploitation of early medieval aquatic environments in Poland and other Baltic Sea countries: an archaeozoological consideration. L'acqua nei secoli alto medievali. Atti della Settimane di studi, Spoleto, pp 253-777

Makowiecki D (2008b) Sturgeon fishing on Polish lowland during Holocene. In: Béarez P, Grouard S, Clavel B (eds) Archéologie du Poisson. Éditions APDCA, Antibes, pp 327-339

Matolcsi J (1981) Mittelalterliche Tierknochen aus dem Dominikanerkloster von Buda. Fontes Archaeologici Hungariae 1981:203-254

Matolcsi J (1982) Tierknochenfunde von Sarvaly aus dem 15.-16. Jahrhundert. In: Holl I, Parádi N (eds) Das mittelalterliche Dorf Sarvaly. Akadémiai Kiadó, Budapest, pp 230-253

Morales A, Rosenlund K (1979) Fish bone measurements. An attempt to standardize the measuring of fish bones from archaeological sites. Steenstrupia, Copenhagen

Nussbaumer M, Rehazek A (2007) Fish remains from a 16th century noble household in Unterseen, Bernese Oberland, Switzerland. In: Hüster-Plogmann $\mathrm{H}$ (ed) The role of fish in ancient time. Verlag Marie Leidorf GmbH, Rahden/Westfalen, pp 107-112

Nyáry A (1867) Az esztergomi érsekség és az egri püspökség számadási könyvei a XV-XVI. századból. Századok 1(4):378-384

Nyáry A (1870) A modenai Hyppolit kódexek. Századok 4:355-370

Nyáry A (1872) A modenai Hyppolit kódexek. Századok 6:287-305

Pénzes B, Tölg I (1977) Halbiológia horgászoknak. Natura-MOHOSZ, Budapest

Pesty F (1867) Magyarország régi vízhálózata. Századok 1:67-68

Pike-Tay A, Bartosiewicz L, Gál E, Whittle A (2004) Body-part representation and seasonality: sheep/goat, bird and fish remains from early Neolithic Ecsegfalva 23, SE Hungary. Journal of Taphonomy 2(4):221-246

Piličiauskienė G, Blaževičius P (2019) Archaeoichthyological and historical data on fish consumption in Vilnius Lower Castle during the 14th-17th centuries. Estonian Journal of Archaeology 23(1):39-55

Rumpolt M (1581) Ein new Kochbuch. Verlag Sigmund Feyerabendt, Franckfort am Mayn

Schmelzl W (1547) Ein Lobspruch der hochlöblichen und weitberühmten Stadt Wien in Österreich. Karl Rauchs Nachfolgern, Wien

Serjeantson D (2001) A dainty dish: consumption of small birds in late medieval England. In: Buitenhuis H, Prummel W (eds) Animals and man in the past. ARC-Publicatie 41, Groningen, pp 263-274 
Spitzenberger F (1983) Die Tierknochen funde des Hausbergs zu Gaiselberg, einer Wehranlage des 12.-16. Jahrhunderts in Niederösterreich. Zeitschrift fur Archäologie des Mittelalters 11:139

Takács I (1987) Segédlet szubfosszilis harcsák testnagyságának kiszámításához a fő vázalkotók méretei alapján. A Magyar Mezőgazdasági Múzeum Közleményei 1987:105-126

Tóth P, Kubinyi A (1996) Miskolc története (A kezdetektől 1526-ig). 1. Borsod-Abaúj-Zemplén Megyei levéltár, Miskolc
Weiperth A, Tóth B, Sevcsik A, Keresztessy K (2015) Halfaunisztikai adatgyüjtés a Visegrádi-hegység két patakjában. Pisces Hungarici 9: $51-54$

Zolnay L (1977) Kincses Magyarország. Magvető Kiadó, Budapest

Publisher's note Springer Nature remains neutral with regard to jurisdictional claims in published maps and institutional affiliations. 